\title{
Natural Analcime Zeolite Modified with 5-Br-PADAP for the Preconcentration and Anodic Stripping Voltammetric Determination of Trace Amount of Cadmium
}

\author{
Darush AfZali, ${ }^{* \dagger}$ Ali Mostafavi,* Mohammad Ali TAher, ${ }^{*}$ Ebrahim Rezaeipour, $*$ and \\ Mohammad KhaYaTZADEH MAHANi**
}

* Department of Chemistry, Shahid Bahonar University of Kerman, Kerman, Iran

**Faculty of Chemistry, Tarbiat Moallem University of Tehran, Tehran, Iran

\begin{abstract}
A procedure for separation and preconcentration of trace amounts of cadmium has been proposed. A column of analcime zeolite modified with benzyldimethyltetradecylammonium chloride and loaded with 2-(5-bromo-2-pyridylazo)-5diethylaminophenol (5-Br-PADAP) was used for retention of cadmium. The cadmium was quantitatively retained on the column at $\mathrm{pH} \sim 9$ and was recovered from column with $5 \mathrm{ml}$ of $2 \mathrm{M}$ nitric acid with a preconcentration factor of 140 . Anodic stripping differential pulse voltammetry was used for determination of cadmium. A $0.05 \mathrm{ng} / \mathrm{ml}$ detection limit for the preconcentration of aqueous solution of cadmium was obtained. The relative standard deviation (RSD) for eight replicate determinations at the $1 \mu \mathrm{g} / \mathrm{ml}$ cadmium levels was $0.31 \%$ (calculated with the peak height obtained). The calibration graph using the preconcentration system was linear from 0.01 to $150 \mu \mathrm{g} / \mathrm{ml}$ in final solution with a correlation coefficient of 0.9997 . For optimization of conditions, various parameters such as the effect of $\mathrm{pH}$, flow rate, instrumental conditions and interference of number of ions, were studied in detail. This method was successfully applied for determination of cadmium in various complex samples.
\end{abstract}

(Received August 26, 2004; Accepted October 26, 2004)

\section{Introduction}

Environmental studies of cadmium as a cumulative toxic metal are increasing recently. Kidney, liver, lung and pancreas are the main organs of human for accumulation of cadmium. Cadmium toxicity may be manifested by a variety of syndromes and effects including renal dysfunction, hypertension, hepatic injury, lung damage and teratogenic effects.

Solid phase extraction (SPE) is one of the most important methods for separation and preconcentration of trace elements in samples. ${ }^{2-6}$ In the solid phase extraction, various sorbents such as thiol cotton, ${ }^{7}$ activated carbon, ${ }^{8}$ adsorption resins, ${ }^{9}$ cellulose, ${ }^{10}$ polythioether, ${ }^{11}$ microcrystalline naphthalene, ${ }^{12-14}$ Amberlite XAD-2 resin, ${ }^{15}$ octadecylsilica membrane disk ${ }^{16}$ and synthetic zeolites ${ }^{17}$ have been used. Some of these adsorbents may be fairly effective for preconcentration of metal ions, but methods of preparation for these adsorbent are lengthily and require rigid control of conditions.

Anodic stripping voltammetry has always been regarded as one of the most sensitive techniques for trace metal analysis. ${ }^{18-21}$ The very low detection limits achieved by anodic stripping voltammetry are due to the preconcentration of the analyte from the sample solution during the deposition step.

Zeolites are highly crystalline alumino-silicate frameworks comprising $\left[\mathrm{SiO}_{4}\right]^{4-}$ and $\left[\mathrm{AlO}_{4}\right]^{5-}$ tetrahedral units. An oxygen bridge joins $\mathrm{Si}$ and $\mathrm{Al}$ atoms. Neutralization of an overall negative surface charge requires counter ions (e.g., $\mathrm{Na}^{+}, \mathrm{K}^{+}$and

$\dagger$ To whom correspondence should be addressed.

E-mail: darush_afzali@yahoo.com
$\left.\mathrm{Ca}^{2+}\right)$. Due to the charged nature of the framework and its ability to form Bronsted acid sites, zeolites are useful for many applications. ${ }^{17}$ It is believed that the ability of zeolite as an adsorbent for organic compounds and metal ions arises from adsorption of cationic surfactants onto zeolites. ${ }^{22}$ Zeolites have been used in separation processes and purification processes like gas sweetening and air decontamination. ${ }^{23}$

In the present work, we have developed a simple, sensitive and economical method for determination of cadmium. In this method cadmium was adsorped onto modified analcime zeolite and then was recovered by $5.0 \mathrm{ml}$ of $2 \mathrm{M}$ nitric acid. After these steps, the solution was transferred to a polarographic cell and cadmium was determined by anodic stripping differential pulse voltammetry. Nitric acid also acts as a supporting electrolyte. Various parameters have been evaluated. It was found that the method is highly selective, rapid, economical and sensitive. The developed procedure was applied to various samples for determination of cadmium.

\section{Experimental}

\section{Apparatus and reagents}

Voltammograms were recorded with a three-electrode system. A computerized Metrohm 757 VA polarograph was used for voltammetric measurements. A funnel tipped glass tube $(80 \times$ $10 \mathrm{~mm}$ ) was used as a column for preconcentration. It was plugged with polypropylene fibers and then was filled with a flat glass rod. All glassware and columns were washed with mixtures of concentrated sulfuric acid and concentrated nitric acid $(1+1)$ before use. A Corning $140 \mathrm{pH}$ meter was used for 


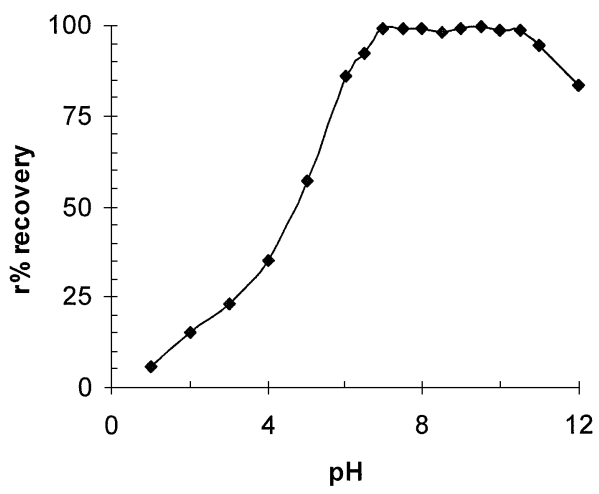

Fig. 1 Effect of $\mathrm{pH}$ on adsorption of cadmium. Condition: cadmium, $5.0 \mu \mathrm{g}$ and instrumental settings; deposition time, $60 \mathrm{~s}$; deposition potential, $-0.8 \mathrm{~V}$; pulse amplitude, $0.05 \mathrm{~V}$; pulse time, 0.4 $\mathrm{s}$; scan rate, $15 \mathrm{mV} \mathrm{s}^{-1}$; purge time, $300 \mathrm{~s}$.

pH measurements. Cadmium nitrate solution was prepared by dissolving the analytical grade sample in doubly distilled water and was standardized by known methods. ${ }^{24}$ A $0.05 \%$ solution of 5-Br-PADAP in ethanol was prepared. Benzyldimethyltetradecylammonium chloride was dissolved in water to obtain a solution of $0.0001 \mathrm{M}$. Solutions of alkali metal salts $(1 \%)$ and various metal salts $(0.1 \%)$ were used for studying of anionic and cationic interferences, respectively. Ammonia buffer ( $\mathrm{pH}$ 9) solution was prepared by mixing of $0.5 \mathrm{M}$ ammonia and $0.5 \mathrm{M}$ ammonium acetate solutions in appropriate ratios. Natural analcime zeolite was collected from Torfeh, Shahr Babak area, Kerman region in Iran. ${ }^{25}$ The $\mathrm{Ag} / \mathrm{AgCl}$ electrode served as the reference electrode and a hanging mercury-dropping electrode (HMDE) was used as a working electrode. A Pt wire was used as auxiliary electrode.

\section{Preparation of modified analcime zeolite}

After purification of analcime, ${ }^{26}$ the zeolite was sieved to obtain a particle size of $<45 \mu \mathrm{m}$ (350 mesh). A 20 -ml volume of nitric acid ( $3 \mathrm{M}$ ) was added to $5 \mathrm{~g}$ zeolite and then distilled water was passed to remove the excess nitric acid. The modification of zeolite was performed as follows: $10 \mathrm{ml}$ of benzyldimethyltetradecylammonium chloride solution $(0.0001$ M) was added to zeolite and the mixture was heated at $110^{\circ} \mathrm{C}$ for $12 \mathrm{~h}$ while being stirred. Then the adsorbent in this form was dried at $110^{\circ} \mathrm{C}$ in an oven and was stored in a calcium chloride desiccator until use.

Preparation of modified analcime zeolite column loaded with 5Br-PADAP

One gram of the modified analcime zeolite was added to a funnel-tipped glass tube and was treated with ethanol:hydrochloric acid:water (2:1:1) solution overnight. Then $5 \mathrm{ml}$ of $0.05 \%$ solution of 5-Br-PADAP in ethanol was passed through it at a flow rate of $2 \mathrm{ml} \mathrm{min}^{-1}$. All experiments were done in a funnel-tipped glass tube $(80 \times 10 \mathrm{~mm})$ as a column for preconcentration. Before sample loading, the column must be preconditioned by passing a buffer solution through it. After conditioning, the column could be used repeatedly for at least ten times. The recovery for cadmium after ten uses of the column is less than of $95 \%$.

\section{Procedure for the sorption of cadmium on the column}

A sample solution of cadmium ions containing 0.05 to $750 \mu \mathrm{g}$ was transferred into a beaker and $5 \mathrm{ml}$ of buffer solution $(\mathrm{pH}$
Table 1 Effect of diverse ions on the cadmium determination ${ }^{\text {a }}$

\begin{tabular}{|c|c|c|}
\hline Ion & $\begin{array}{l}\text { Chemical form } \\
\text { of the compound }\end{array}$ & $\begin{array}{l}\text { Tolerance } \\
\text { limit/mg }\end{array}$ \\
\hline $\mathrm{CH}_{3} \mathrm{COO}^{-}$ & $\mathrm{CH}_{3} \mathrm{COONa}$ & 720 \\
\hline $\mathrm{NO}_{3}^{-}$ & $\mathrm{KNO}_{3}$ & 740 \\
\hline $\mathrm{SO}_{4}{ }^{2-}$ & $\mathrm{K}_{2} \mathrm{SO}_{4}$ & 390 \\
\hline EDTA & $\mathrm{Na}_{2}$ EDTA & 0.09 \\
\hline $\mathrm{I}^{-}$ & KI & 300 \\
\hline $\mathrm{SCN}^{-}$ & KSCN & 50 \\
\hline $\mathrm{NH}_{4}^{+}$ & $\mathrm{NH}_{4} \mathrm{Cl}$ & 520 \\
\hline $\mathrm{Mn}^{2+}$ & $\mathrm{MnSO}_{4}$ & 300 \\
\hline $\mathrm{Zn}^{2+}, \mathrm{Hg}^{2+}$ & $\mathrm{ZnCl}_{2}, \mathrm{Hg}\left(\mathrm{NO}_{3}\right)_{2}$ & 200 \\
\hline $\mathrm{Co}^{2+}$ & $\mathrm{Co}\left(\mathrm{NO}_{3}\right)_{2}$ & 900 \\
\hline $\mathrm{Bi}^{3+}$ & $\mathrm{Bi}\left(\mathrm{NO}_{3}\right)_{3}$ & 7.5 \\
\hline $\mathrm{V}^{5+}$ & $\mathrm{V}_{2} \mathrm{O}_{5}$ & 10 \\
\hline $\mathrm{As}^{3+}$ & $\mathrm{As}_{2} \mathrm{O}_{3}$ & 0.4 \\
\hline $\mathrm{Cu}^{2+}$ & $\mathrm{Cu}\left(\mathrm{NO}_{3}\right)_{2}$ & 100 \\
\hline $\mathrm{Tl}^{+}$ & $\mathrm{TINO}_{3}$ & 500 \\
\hline $\mathrm{Ni}^{2+}$ & $\mathrm{Ni}\left(\mathrm{NO}_{3}\right)_{2}$ & 2.3 \\
\hline $\mathrm{Pb}^{2+}$ & $\mathrm{Pb}\left(\mathrm{NO}_{3}\right)_{2}$ & 4.2 \\
\hline $\mathrm{Mg}^{2+}$ & $\mathrm{Mg}\left(\mathrm{NO}_{3}\right)_{2}$ & 230 \\
\hline $\mathrm{Al}^{3+}$ & $\mathrm{AlCl}_{3}$ & 50 \\
\hline $\mathrm{Sb}^{3+}$ & $\mathrm{SbCl}_{3}$ & 7.4 \\
\hline
\end{tabular}

a. The sample contained $5 \mu \mathrm{g}$ of cadmium and given amounts of foreign ion in a $5.0 \mathrm{ml}$ sample solution of nitric acid.

-9) was added to the beaker. This solution was passed through the column at a flow rate of $5.0 \mathrm{ml} \mathrm{min}{ }^{-1}$. After passing, the column was washed with $5 \mathrm{ml}$ of deionized water. The adsorbed cadmium on the column was recovered with $5.0 \mathrm{ml}$ nitric acid solution at a flow rate of $2.0 \mathrm{ml} \mathrm{min}{ }^{-1}$. The eluent was collected in a $5 \mathrm{ml}$ volumetric flask and cadmium was determined by anodic stripping differential pulse voltammetry.

\section{Results and Discussion}

Preliminary studies with analcime and modified analcime zeolites

At first we investigated the potential of the analcime zeolite for separation and preconcentration of cadmium. In this work we used $5 \mu \mathrm{g}$ of cadmium with $5 \mu \mathrm{g}$ of the other cations that were mentioned in diverse ions; the results showed recovery for cadmium less than 50\%. Therefore the analcime zeolite without modification was not suitable for separation and preconcentration of cadmium. Therefore, 5-Br-PADAP reagent was added to zeolite, and then modified zeolite was studied for separation and preconcentration. The results showed that modified zeolite with 5-Br-PADAP was suitable for separation and preconcentration of cadmium (recovery for $5 \mu \mathrm{g}$ of cadmium is more than $96 \%$ ) but sorption capacity and linear range for determination were low. A recent work ${ }^{25}$ indicated that modification of zeolite with a cationic detergent increased the sorption capacity of the zeolite for organic materials. Therefore, benzyldimethyltetradecylammonium chloride was added to analcime. This detergent increased the adsorption of 5-Br-PADAP reagent, so it was recognized that sorbent could be used for separation and preconcentration of trace amounts of cadmium. The modified analcime with benzyldimethyltetradecylammonium chloride that was loaded with 5-BrPADAP was selective and sensitive for separation and preconcentration of trace amounts of cadmium. On the other hand, the modification of zeolite only with benzyldimethyltetradecylammonium chloride was evaluated for 
Table 2 Analysis of samples for cadmium

\begin{tabular}{|c|c|c|c|}
\hline \multirow[b]{2}{*}{ Sample } & \multirow[b]{2}{*}{ Composition, $\%$} & \multicolumn{2}{|c|}{ Concentration of cadmium } \\
\hline & & $\begin{array}{c}\text { Certified } \\
\text { value }\end{array}$ & Found $^{\mathrm{a}}$ \\
\hline $\begin{array}{l}\text { NIST SRM } \\
629 \text { Zinc Alloy }\end{array}$ & $\begin{array}{l}\mathrm{Fe}, 0.017 ; \mathrm{Cu}, 1.50 ; \\
\mathrm{Al}, 5.15 ; \mathrm{Mg}, 0.094 ; \\
\mathrm{Sn}, 0.012 ; \mathrm{Cr}, 0.0008 \\
\mathrm{Mn}, 0.0017 ; \mathrm{Ni}, 0.0075 \\
\mathrm{~Pb}, 0.0135 ; \mathrm{Si}, 0.078\end{array}$ & 0.0155 & $0.0152 \pm 0.002$ \\
\hline $\begin{array}{l}\text { NISI SRM } \\
\text { 94c Zn-Base } \\
\text { Die Casting } \\
\text { Alloy }\end{array}$ & $\begin{array}{l}\mathrm{Sn}, 0.006 ; \mathrm{Ni}, 0.006 ; \\
\mathrm{Mn}, 0.014 ; \mathrm{Fe}, 0.018 ; \\
\mathrm{Mg}, 0.042 ; \mathrm{Cu}, 1.01 ; \\
\mathrm{Pb}, 0.006 ; \mathrm{Al}, 4.13\end{array}$ & 0.0020 & $0.0019 \pm 0.0002$ \\
\hline $\begin{array}{l}\text { NIST SRM } \\
627 \text { Zn-Base } \\
\text { Alloy CE }\end{array}$ & $\begin{array}{l}\mathrm{Cu}, 0.132 ; \mathrm{Mg}, 0.030 \\
\mathrm{Fe}, 0.023 ; \mathrm{Sn}, 0.0042 \\
\mathrm{Cr}, 0.0038 ; \mathrm{Mn}, 0.014 \\
\mathrm{Ni}, 0.0029 ; \mathrm{Si}, 0.021 \\
\mathrm{~Pb}, 0.0083 ; \mathrm{Al}, 3.88\end{array}$ & 0.005 & $0.0047 \pm 0.0004$ \\
\hline $\begin{array}{l}\text { NIST SRM } \\
627 \text { Zn-Base } \\
\text { Alloy E }\end{array}$ & $\begin{array}{l}\mathrm{Cu}, 0.50 ; \mathrm{Mg}, 0.094 ; \\
\mathrm{Fe}, 0.17 ; \mathrm{Sn}, 0.012 ; \\
\mathrm{Cr}, 0.0008 ; \mathrm{Mn}, 0.017 \\
\mathrm{Ni}, 0.0075 ; \mathrm{Si}, 0.078 \\
\mathrm{~Pb}, 0.0135 ; \mathrm{Al}, 5.15\end{array}$ & 0.0150 & $0.016 \pm 0.003$ \\
\hline
\end{tabular}

a. Mean of five determinations \pm standard deviation.

separation and preconcentration of trace amounts of cadmium ion. The results were indicated recovery for $5 \mu \mathrm{g}$ of cadmium less than $70 \%$ and this sorbent, like as analcime zeolite (without modification), is not selective and not suitable for separation of cadmium ion.

\section{Anodic stripping differential pulse voltammetry}

In this work, the differential pulse voltammogram for cadmium was obtained in $\mathrm{HNO}_{3}$ medium as supporting electrolyte. Sample solutions were transferred into a voltammetric cell. The solution was deaerated for $5 \mathrm{~min}$ with the nitrogen gas. The voltammograms were recorded by sweeping the potential from -0.2 to $-0.8 \mathrm{~V}$ versus reference electrode. Cadmium was deposited on a hanging mercury drop electrode at $-0.9 \mathrm{~V}$ for $60 \mathrm{~s}$, while the solution was being stirred. The amalgamate cadmium was stripped by differential pulse voltammetry with scanning of electrode potential from -0.2 to $-0.8 \mathrm{~V}$, with scan rate of $0.015 \mathrm{~V} \mathrm{~s}^{-1}$ and pulse amplitude of $5 \mathrm{mV}$.

\section{Reaction conditions}

The effect of $\mathrm{pH}$ on adsorption of cadmium was studied by calculating the percentage of recovery for metal ion on the adsorbent in 1 to $12 \mathrm{pH}$ range. The results are shown in Fig. 1. Cadmium was adsorbed quantitatively between 7.0 to 10.5 .

The flow rate was varied from 0.5 to $6 \mathrm{ml} \mathrm{min}^{-1}$ and did not affect the adsorption. A flow rate of $5.0 \mathrm{ml} \mathrm{min}^{-1}$ was recommended in all experiments.

The volume of the aqueous phase was varied in the range of $50-1000 \mathrm{ml}$ under optimum conditions. It was observed that the adsorption was almost constant up to $700 \mathrm{ml}$ aqueous phase. However, for convenience, all the experiments were carried out with $50 \mathrm{ml}$ of aqueous phase.

Many organic and inorganic solvents were examined as possible eluents. With organic solvents, 5-Br-PADAP reagent leaves the column, so these were not suitable. With nitric acid, cadmium was desorbed completely and 5-Br-PADAP reagent
Table 3 Analysis of cadmium in water samples

\begin{tabular}{lcc}
\hline \multicolumn{1}{c}{$\begin{array}{c}\text { Sample/ } \\
\text { water }\end{array}$} & $\begin{array}{c}\text { Cadmium found } \\
\text { by present method }\end{array}$ & $\begin{array}{c}\text { Cadmium found } \\
\text { by AAS }\end{array}$ \\
\hline Well water & $4.4 \pm 0.1$ & $4.5 \pm 0.2$ \\
River water & $0.78 \pm 0.02$ & - \\
Tap water (Kerman) & $1.24 \pm 0.04$ & $1.27 \pm 0.08$ \\
Tap water (Shiraz) & $1.58 \pm 0.05$ & $1.5 \pm 0.1$ \\
Tap water (Tehran) & $1.40 \pm 0.03$ & $1.5 \pm 0.1$ \\
\hline
\end{tabular}

a. Mean of five determinations \pm standard deviation after preconcentration and determination of cadmium by present method. b. Mean of five determinations \pm standard deviation, and cadmium was determined by graphite furnace atomic absorption spectrometry.

did not leave the column. The concentration of nitric acid was varied between 0.1 to $5 \mathrm{M}$, and we observed that optimum recovery of cadmium was obtained in $2-5 \mathrm{M}$ concentration range. Therefore, $5.0 \mathrm{ml}$ of $2 \mathrm{M}$ nitric acid was used in the present work.

\section{Sorption capacity}

The sorption capacity of the modified analcime zeolite loaded with 5-Br-PADAP was evaluated. In this case, the column containing $1.0 \mathrm{~g}$ of modified analcime zeolite was used and different volumes of cadmium solution (100 ppm) were passed through the column until cadmium was detected in solution after passing. The modified analcime zeolite had a sorption capacity of $1.65 \mathrm{mg}$ of cadmium per gram of modified analcime zeolite.

\section{Calibration and sensitivity}

After $700 \mathrm{ml}$ of solution had passed through the column, $0.035 \mu \mathrm{g}$ of cadmium was adsorbed on analcime zeolites; desorption with $5.0 \mathrm{ml}$ nitric acid gives a detection limit of 0.05 $\mathrm{ng} / \mathrm{ml}$ for cadmium at the minimum instrumental settings. The linearity was maintained in the cadmium concentration range between $0.07 \mathrm{ng} / \mathrm{ml}$ to $1.07 \mu \mathrm{g} / \mathrm{ml}$ in first aqueous solution or 0.01 to $150 \mu \mathrm{g} / \mathrm{ml}$ in final nitric acid solution, with a correlation coefficient of $0.9995(y=0.8535 x+0.065)$ and relative standard deviations of $0.31 \%$.

\section{Interferences}

Various salts and metal ions were added individually to cadmium solution (5 $\mu \mathrm{g}$ cadmium) and cadmium was determined. The tolerance limit (error $<3 \%$ ) is given in Table 1. Observations showed that this procedures free from interferences even at milligram or gram level. Thus the method is highly selective without use of masking agents. The proposed procedure was applied to the determination of cadmium in alloys and biological samples without any prior separations.

\section{Determination of cadmium in standard alloys}

The proposed method was applied to the determination of cadmium in National Institute of Standards and Technology, Standard Reference Materials NIST SRM 629 Zinc Alloy, NIST SRM 94c Zn-Base Die Casting Alloy, NIST SRM 627 Zn-Base Alloy CE, NIST SRM 629 Zn-Base Alloy E. A $0.1 \mathrm{~g}$ sample of these standard alloys was completely dissolved in $6-14 \mathrm{ml}$ of hydrochloric acid $(1+1)$ while heating on a water-bath and then $1 \mathrm{ml}$ of $30 \%(\mathrm{v} / \mathrm{v})$ hydrogen peroxide was added to it. Heating the sample on the water-bath decomposed the excess of peroxide. Then the solution was cooled, filtered (if needed) and 
Table 4 Analysis of cadmium in standard Pepperbush

\begin{tabular}{|c|c|c|}
\hline \multirow{2}{*}{ Sample } & \multicolumn{2}{|c|}{ Concentration of cadmium $/ \mu \mathrm{g} \mathrm{g}^{-1}$} \\
\hline & Certified value & Found $^{\mathrm{a}}$ \\
\hline NIES, No. 1 Pepperbush & $6.7 \pm 0.5$ & $6.5 \pm 0.4$ \\
\hline NIES, No. 3 Chlorella & 0.026 & $0.025 \pm 0.003$ \\
\hline NIES, No. 6 Mussels & $0.82 \pm 0.03$ & $0.80 \pm 0.03$ \\
\hline NIES, No. 2 Pond Sediment & 0.82 & $0.84 \pm 0.04$ \\
\hline
\end{tabular}

a. Mean of five determinations \pm standard deviation.

diluted to $100 \mathrm{ml}$ with distilled water in a standard flask. An aliquot $(50-100 \mathrm{ml})$ of the pretreated sample solution was taken and was analyzed by the general procedure. The results are given in Table 2; they are in good agreement with the certified values.

Determination of cadmium in natural water samples

The proposed method was applied to the determination of cadmium in water samples. A $150 \mathrm{ml}$ sample of natural water was adjusted to $\mathrm{pH}=1$ with nitric acid and filtered for removal of suspended material. Then $10 \mathrm{ml}$ buffer with $\mathrm{pH}=9$ was added to it and it was diluted to $200 \mathrm{ml}$ in standard flask. This solution was passed through the column and analyzed by the general procedure. The results were compared with those obtained by graphite furnace atomic absorptin spectrometry (Table 3).

Determination of cadmium in pepperbush, chlorella, mussel and pond sediment

For the accuracy and applicability purposes, the method was applied to several samples: National Institute for Environmental studies (NIES) No. 1, Pepperbush; NIES, No. 3, Chlorella; NIES, No. 6, Mussels and NIES, No. 2, Pond Sediment. A 0.1 $\mathrm{g}$ sample was taken in a beaker and was dissolved in concentrated nitric acid $(\sim 5 \mathrm{ml})$ with heating. The solution was cooled, diluted, and filtered. After filtration, each solution was diluted to $100 \mathrm{ml}$ in a calibrated flask. An aliquot $(50-100 \mathrm{ml})$ of the pretreated sample solution was taken and was analyzed by the general procedure. The results are given in Table 4; they are in good agreement with the certified values.

\section{Conclusions}

The main advantages of this procedure are: (I) natural analcime is very cheap; (II) the preparation of the extractor system is simple and fast; (III) during cadmium desorption, the 5-BrPADAP reagent remains in the modified zeolite; this allows using the column for ten times; (IV) a good enrichment factor (140) can be achieved. The achieved recovery (measured by standard addition technique) showed that the proposed procedure had good accuracy. The proposed procedure was applied for cadmium determination in various samples. 5-BrPADAP reagent is fairly sensitive and selective for cadmium, but with preconcentration and anodic stripping differential pulse voltammetry, its sensitivity and its selectivity were improved. It is not possible to develop selective methods for metal ions using this adsorbent in spectrophotometry, since many metal-5-BrPADAP complexes absorb at close wavelengths. However, with anodic stripping differential pulse voltammetry, this problem was solved. The proposed procedure was applied for cadmium determination in various samples.

\section{References}

1. F. W. Oehme, "Toxicity of Heavy Metals in the Environment", 1978, Marcel Dekker, New York.

2. Y. Sakai and N. Mor, Talanta, 1986, 33, 161.

3. E. Jackwerth, X. G. Yang, C. Xu, and Z. Fresen, Anal. Chem., 1989, 334, 514.

4. M. Soylak and L. Elci, J. Trace Microprobe Tech., 2000, $18,346$.

5. Kh. Brainina and E. Neyman, "Electroanalytical Stripping Methods", 1993, Wiley, New York.

6. J. Wang, "Stripping Analysis: Principles, Instrumentation and Applications", 1985, VCH Publishers, Deerfield Beach.

7. M. Q. Yu, G. Q. Liu, and Q. Jin, Talanta, 1983, 30, 265.

8. B. M. Vanderborght and R. E. Vangrieken, Anal. Chem., 1977, 40, 311.

9. M. Soylak and L. Elci, Int. J. Environ. Anal. Chem., 1997, 66, 51.

10. P. Burba and P. G. Willmer, Talanta, 1983, 30, 381.

11. A. S. Khan and A. Chow, Talanta, 1986, 33, 182.

12. M. A. Taher, Anal. Sci., 2001, 17, 969.

13. M. A. Taher, Talanta, 2000, 52, 181.

14. M. A. Taher and B. K. Puri, Talanta, 1999, 48, 355.

15. S. L. C. Ferreria, C. F. D. Brito, and A. F. Danats, Talanta, 1999, 48, 1137.

16. M. Bagheri, M. H. Mashhadizadeh, and S. Razee, Talanta, 2003, 60, 839.

17. Y. P. Pena, W. Lopez, J. L. Burguera, M. Burguera, M. Gallignani, R. Brunetto, P. Carrero, C. Rondon, and R. Imbert, Anal. Chim. Acta, 2000, 403, 249.

18. F. Vydra, K. Stulik, and E. Julakova, "Electrochemical Stripping Analysis", 1976, Ellis Horwood, Chichester.

19. Kh. Brainina, "Stripping Voltammetry in Chemical Analysis", 1974, Halsted, New York.

20. R. Kalvoda, "Electroanalytical Methods in Chemical and Environmental Analysis", 1987, Plenum Press, New York.

21. P. T. Kissinger and W. R. Heineman (ed.), "Laboratory Techniques in Electroanalytical Chemistry", 1984, Marcel Dekker, New York.

22. H. Van Bekkum, E. M. Flanigen, and J. C. Jansen (ed.), "Introduction to Zeolite Science and Practice. Studies in Surface Sciences and Catalysis", 1991, Vol. 58, Elsevier, Amsterdam.

23. J. B. Nagy, P. Bodart, I. Hannas, and I. Kivicsi, "Synthesis, Characterization and Use of Zeolitic Microporous Materials", 1998, Decagen, Szeged, Hungary.

24. A. I. Vogel, "A Text Book of Quantitative Chemical Analysis", 6th ed., 2000, Longman, London.

25. H. Faghihian, A. Mostafavi, and A. Mohammadi, J. Sci. I. R. Iran, 2001, 12, 327.

26. Y. V. Seryotkin, V. V. Bakakin, I. A. Belitsky, and B. A. Fursenko, Microporous Mesoporous Mater., 2000, 39, 265. 